\title{
A Conference to Promote Undergraduate Research In the Arab World
}

\author{
By Qusay H. Mahmoud, May AlTaei, and Leon Jololian
}

DOI: 10.1145/2090276.2160982

\begin{abstract}
T
he Arab world, and especially the Arabian Peninsula, is emerging as a new hub for education. Universities are striving to enhance their research portfolios and establish industry collaborations. Engaging undergraduate students in research is crucial for many of the undergraduate-focused academic institutions, not only because it will help develop students' critical and creative thinking skills, but also expand their creativity and innovation, and encourage students to develop researchbased product concepts leading to employment opportunities in a region with the highest youth unemployment rate in the world. Here we present our experience in establishing a successful conference model for promoting undergraduate research in the Arab world.
\end{abstract}

Undertaking research is a new experience for many students worldwide and students in the Arab world are no different. Exposing and engaging students in research is very important as it will help them sharpen their critical and creative thinking skills, and possibly their entrepreneurial spiritespecially in a region where there is very limited high-technology exports.

Studies have shown engaging students in research will enhance their educational experience, encourage them to pursue further research, allow them to develop skills to work independently and as part of a team, improve their writing, communication, and presentation skills [1]. Furthermore, students will gain insight into the effort involved in doing research and experience the excitement (and frustration) of knowledge discovery and creation, innovation, and dissemination of results.

Engaging undergraduate students in faculty research is particularly important in the Arab world where research-active faculty, despite limited funding, may have little to no access to graduate students due to the lack of graduate programs in their departments or a research-based graduate programs. Hence, engaging students in research could bring benefits to students, faculty, and academic institutions. It helps in student recruitment and retention, serves as a great vehicle for recruiting graduate students for those universities with graduate programs, and encourages participation from the industry. Given the number of women studying science and engineering in the Arab world, an undergraduate conference would further promote women's interest in computing and technology.

According to the Education for Employment initiative (http://www. e4eArabYouth.com), headed by the International Finance Corporation, the Arab world suffers from the highest youth unemployment rate in the world, currently recorded at 25 percent. Female youth unemployment is even higher, reaching 30 percent across the Arab world. Note that one third of the Arab world is below the age of 15, and another third is aged between 15-29. We believe research and development will help in creating job opportunities, and hence the importance of engaging students in research. To this end, opening new doors of hope, especially in the face of a high unemployment rate among youth in the region.

\section{URC.AC}

It is universally accepted that students work on a capstone project during their final year of study, especially in technical programs, and that's also the case at educational institutions in the Arab world. The capstone project can be done over one semester and in some cases two semesters. We initially wanted to provide a forum for students in the United Arab Emirates (UAE) to present their capstone projects, and hence the Undergraduate Research Conference on Applied Computing was established (http:// www.urc.ac). The positive feedback we have received from participants in URC2009 and the students' excitement observed during the conference encouraged us to expand the conference into a longer event that is open to the Arab world.

The objective of the conference is to promote research activity at educational institutions in the region, by providing a forum for students to 
present their research and interact with other young researchers, faculty, and industry leaders.

Faculty manages the submission and review process, however student volunteers play a key role in running the conference under the supervision of the conference organizing committee. Student volunteers are actively involved in handling the registration process, directing attendees to sessions, and, in the case of last year's conference, chairing all oral presentation sessions including the keynotes.

In 2009 the conference was a oneday event with participants from institutions across the UAE. In 2010,the conference was extended to two days with participation extended to other Gulf countries, and in 2011 extended to the rest of the Arab world. In the coming years it will continue to expand. The conference has been continually growing; it is worth noting that more than half of the participants are females (see Table 1).

While we initially anticipated all presenting participants to be in their final year of study, we have had some third-year students participate with course-based research projects. In addition to the students presenting and possibly their family members, the conference attendees also include academic advisors (some are expatriate faculty), other students and faculty, and representatives from industry and government organizations. It is worth noting that some of the students attending universities in the Arabian Peninsula are not Arabs; there is a large international student body either as visiting students or those who have relocated with their expatriate parents.

The conference program contains a wide selection of activities, including keynote speakers, oral and poster presentation sessions, a panel discussion on opportunities and challenges in undergraduate research, and an evening reception. The panel is always an exciting conference session whereby students are eager to participate in the discussion.

\section{SUBMISSION AND REVIEW PROCESS}

Students submit a 500-word abstract of their project in English, as it is

Table 1: URC.AC Conference Statistics.

\begin{tabular}{|c|c|c|c|}
\hline Year & $\begin{array}{l}\text { Number of oral } \\
\text { and poster } \\
\text { presentations }\end{array}$ & $\begin{array}{l}\text { Number of } \\
\text { participating } \\
\text { academic } \\
\text { institutions }\end{array}$ & $\begin{array}{c}\text { Number of } \\
\text { participants: } \\
\text { students/faculty } \\
\text { and other }\end{array}$ \\
\hline 2009 & 46 & $\begin{array}{c}11 \\
\text { [from UAE only] }\end{array}$ & $\begin{array}{c}115 / 33 \\
\text { Total: } 148\end{array}$ \\
\hline 2010 & 105 & $\begin{array}{c}24 \\
\text { [from UAE, KSA, Qatar, } \\
\text { Oman, Bahrain] }\end{array}$ & $\begin{array}{l}258 / 75 \\
\text { Total: } \mathbf{3 3 3}\end{array}$ \\
\hline 2011 & 122 & $\begin{array}{l}31 \\
\text { [all of the above, plus } \\
\text { Jordan, Lebanon, Egypt, } \\
\text { Palestine] }\end{array}$ & $\begin{array}{c}291 / 81 \\
\text { Total: } \mathbf{3 7 2}\end{array}$ \\
\hline
\end{tabular}

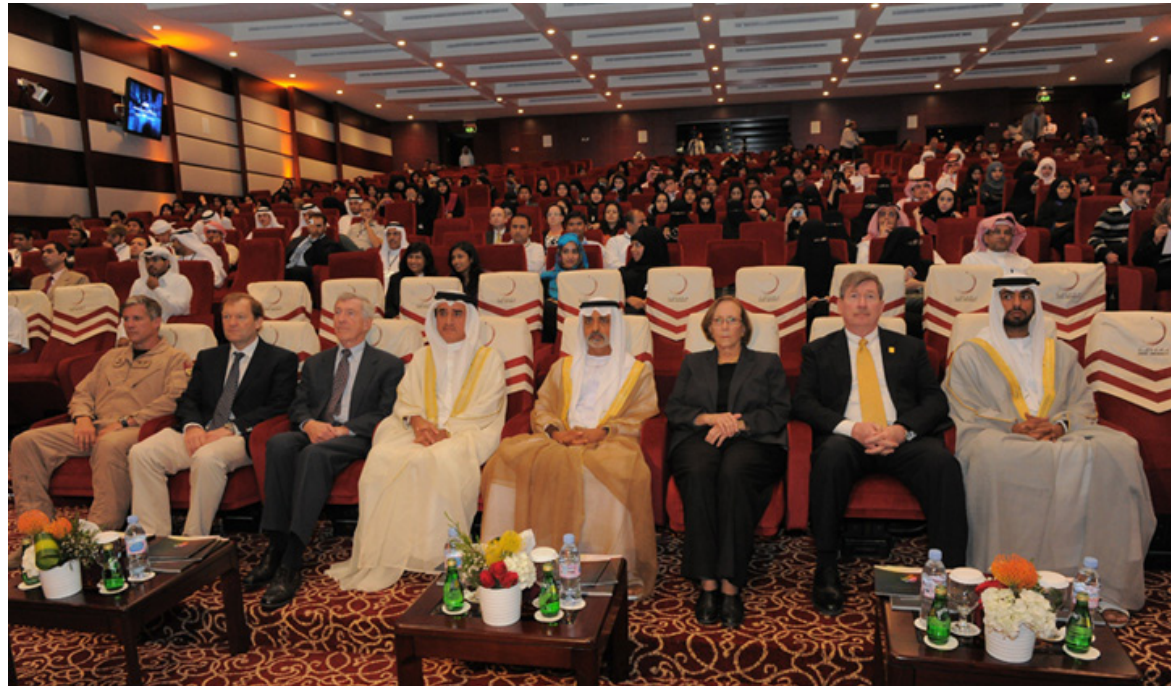

the language of the conference (we use easychair.org for managing submissions). At the initial submission, students specify their presentation preference, oral or poster. Faculty members, who are members of the technical program committee, review all submissions. Students are provided with feedback (two reviews per paper) and given two weeks to address the reviewers' comments and submit their final abstract, which will be published in the book of abstracts. All submissions in the poster category are accepted in that category. However, not all submissions in the oral category are accepted as such; some will be accepted as posters. We try to have around 40 percent of the submissions presented in the oral category and the rest in poster presentations. However, all abstracts (500-words maximum) will be published in the book of abstracts, which is distributed at the conference and is available online.

\section{CONFERENCE BUDGET}

The conference has received financial support from a number of sponsors including the Emirates Foundation, Telecommunication Regulatory Authority (TRA), and Zayed University Research, which provides state-ofthe-art conference facilities. We are thankful for their support in making the conference possible. Students pay a nominal registration fee of approximately $\$ 40$ and this includes the book 


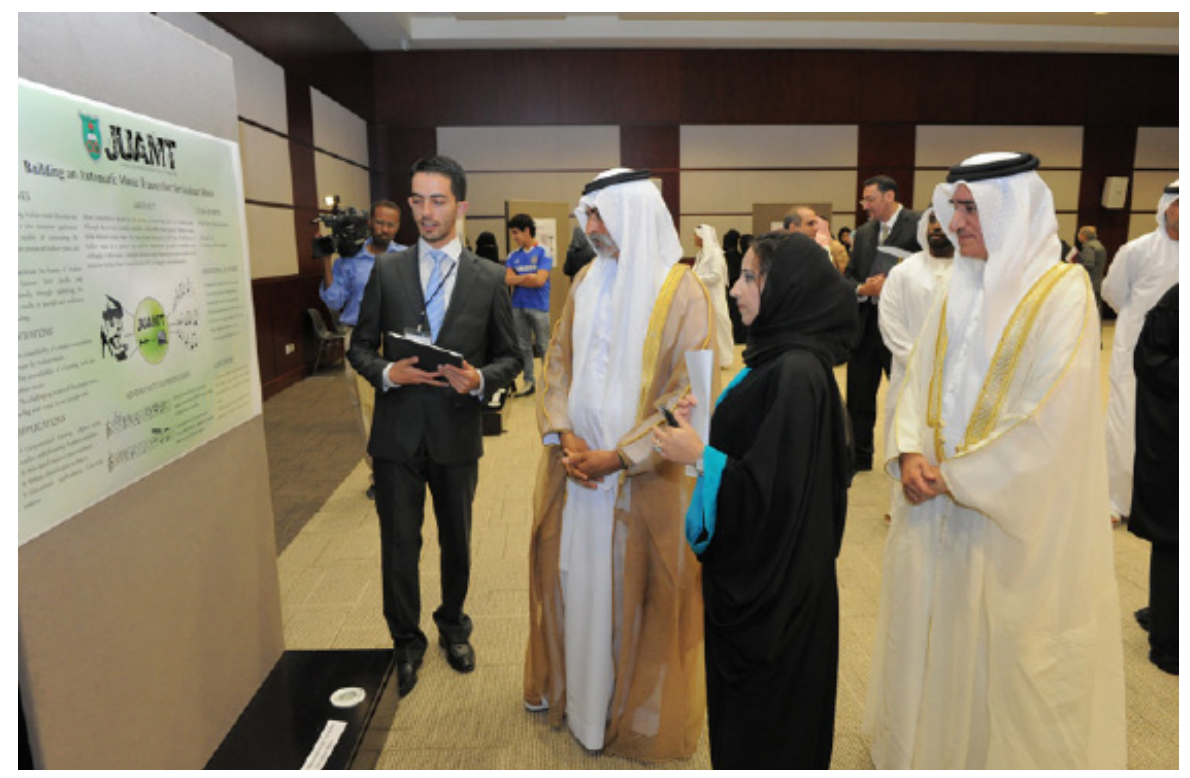

of abstracts, access to all conference sessions, and meals on both days. It doesn't really cost much to run this conference. In 2011, for example, the budget was well below $\$ 15,000$ (generated from sponsors and registration fees), and we were able to provide some travel grants, including registration waiver, to a number of students participating from outside the UAE.

\section{URC2011 AND RESEARCH PUBLICATIONS}

The 2011 conference edition reached new heights. His Excellency Sheikh Nahayan Mabarak Al Nahayan, UAE Minister of Higher Education and Scientific Research and President of Zayed University opened the conference and delivered a keynote speech in which he stressed the importance of research, development, and innovation in building a knowledge-based economy. The President laid out some principles going forward: To engage students into faculty research activities, and to provide them with the necessary mentoring and guidance to enable them to excel in their selected areas of research.

When evaluating research abstracts, faculty members are also asked to comment on the potential applications of the research for best oral or poster presentation award nominations. However, judgment based on a 500-word abstract is not a determinant and hence two independent reviewers evaluate each oral and poster presentation again during the conference. It was an overwhelming task for faculty, but students enjoy the interaction with faculty and the opprotunity to answer questions about their work.

Students with the best oral and poster presentations are given a plaque at the awards ceremony on the second day of the conference. A total of 10 awards were presented at URC2011, five in each of the oral and poster presentations. The awards were presented by Dr. Sulaiman Al Jassim, Vice President of Zayed University, who said: "We need to accelerate the research engine in the region and this conference is a step in the right direction to encourage young researchers to get involved in research projects."

Given the increasing quality of the research presented at the conference, we have invited student authors of the best research projects to extend and submit a full paper for possible publication in a journal special issue. The papers went throgh a review process, and six selected papers from URC201 have since been published in a special issue of the IEEE Multidisciplinary Engineering Education Magazine, which offers a glimpse into some of the interesting research carried out by undergraduate students at educational institutions in Saudi Arabia, UAE, Jordan, Lebanon, and Qatar. The papers reflect the diverse research interests of undergraduate students, which cross a broad spectrum of topics in applied computing.

\section{CONCLUSION}

The URC.AC is a great model for celebrating students' research and their success. In addition to offering a forum for students to present their research, the conference provides them with travel and networking opportunities to meet with other young researchers from the region (and, in the near future, from around the world). Students share the research and development challenges facing their nations and discuss the possible solutions research may offer as opportunities for job creation.

The feedback we have received from participants-including students and their parents, faculty, and leaders from the industry-has been very positive. We hope this conference will help academic institutions in the region shape their undergraduate research to become part of their institutional culture.

We welcome participation from undergraduate students and their advisors from around the world, but if it is too late to submit an abstract by the time you read this article, please consider attending the URC 2012 in April with a group of students. We are certain that you will enjoy the conference and what the UAE has to offer for a great cultural experience. More information about the selection process, winning projects, and photos from the awards ceremony are available at http://www.urc.ac.

\section{Acknowledgments \\ We would like to thank the editors at XRDS for giving us the opportunity to share our conference experience with their readers. We'd also like to take this opportunity to thank all those who have contributed to the success of the URC.}

\section{Biographies}

Qusay H. Mahmoud is a professor of computer science and director of the centre for mobile education and research at the University of Guelph, Canada.

May AlTaei is a faculty member in the college of information technology at Zayed University, United Arab Emirates.

Leon Jololian is the dean of the college of information technology at Zayed University, United Arab Emirates.

\section{References \\ [1] L. Barker. Student and faculty perceptions of undergraduate research experiences in computing. ACM Transactions on Computing Education 9, 1 [2009], 1-28.}

